\title{
Endodontic File Systems with Special Emphasis on Self- adjusting Files: A Comprehensive Review
}

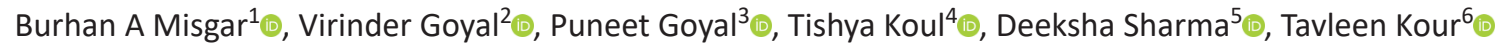

\begin{abstract}
This article represents a thorough understanding in relation to cleaning and shaping of root canal system which is of utmost importance for the success of treatment. Numerous systems and techniques are used for effective cleaning and shaping of the root canals and management and prevention of endodontic disease. This article reviews availability, ease of use, cost- and time-effectiveness, cyclic and torsional fatigue, cross-contamination, shaping ability, cleaning efficacy and removal of smear layer, ability to remain centered, and apical extrusion of various filing systems, which are used in the preparation of canal with special emphasis on self-adjusting files.

Keywords: Endodontic instrumentation, Endodontic rotary system, Root canal file system, Rotary endodontics, Rotary NiTi files, Self-adjusting file system.

Journal of Operative Dentistry and Endodontics (2021): 10.5005/jp-journals-10047-0108
\end{abstract}

\section{INTRODUCTION}

Endodontics (Greek word: Endo meaning inside and Odont meaning tooth) is defined as the branch of dental science concerned with the study of the form, function, health of, injuries to and diseases of the dental pulp and periradicular region and their treatment. ${ }^{1}$ The endo-treatment generally is a procedure of debridement followed by three-dimensional sealing of pulp space and restoration of the tooth. Describing a whole procedure, we can state that endo-treatment is a three-phase procedure: diagnostic, preparatory, and obturation phases. ${ }^{2}$ The preparatory phase, being most important, comprises chemomechanical debridement for purpose of elimination of pulpal tissue, microbiota along with their byproducts, and organic and inorganic debris by instrumentation and irrigation, which prevents the spread of infection and maintains integrity and functioning of teeth and periradicular tissues. ${ }^{3}$ After proper access, the endodontic armamentarium is used for the preparation of teeth which involves removal, cleaning, and shaping of the root canal. The stainless steel (SS) hand files used in the preparation of canals are thought as conventional shaping method. ${ }^{4}$ Armamentaria like hand-operated, machine-driven and rotary instruments have been used to carry out endodontic procedures. But, with the recent evolution of hand-operated and rotary file systems, a paradigm shift has been noticed, keeping in view the potential for usage of time and efficacy. In 1838, Edward Maynard created the first endodontic instrument starting with the spring of clock with objectives of disinfection and enlargement of the canal. ${ }^{5}$ The first instruments were made of carbon steel and gradually replaced by stainless steel. The endodontic armamentarium standardization has been done to improve the quality and lessening of endodontic failure. The International Standards Organization (ISO) working with the Federation Dentaire Internationale (FDI) in the technical committee 106 joint working group (TC-106 JWG-1) established the international standards for endodontic armamentarium. The American National Standards Institute (ANSI) and its committee Z-156 (Dentistry), which was later designated Committee MD-156 (Medical Devices), independently developed the American standards. In 1976, the

\footnotetext{
${ }^{1-6}$ Department of Pediatric and Preventive Dentistry, Guru Nanak Dev Dental College and Research Institute, Sunam, Punjab, India

Corresponding Author: Burhan A Misgar, Department of Pediatric and Preventive Dentistry, Guru Nanak Dev Dental College and Research Institute, Sunam, Punjab, India, Phone: +91 7006040355, e-mail: burhanaltafmisgar95@gmail.com

How to cite this article: Misgar BA, Goyal V, Goyal P, et al. Endodontic File Systems with Special Emphasis on Self-adjusting Files: A Comprehensive Review. J Oper Dent Endod 2021;6(1):14-23.

Source of support: Nil

Conflict of interest: None
}

American National Standard Specification No. 28 was adopted which sets the standards for the manufacture of files and reamers in consideration of their shape, dimensions, and diameter. In 1981, the American Dental Association (ADA) Council on dental materials, instruments, and equipment, along with ANSI, adopted specification number $\mathbf{2 8}$ for the $\mathrm{H}$-type instruments. These guidelines are referred as the standard specifications while as early guidelines are called as conventional specifications. The ISO and FDI joint working group placed endodontic armamentarium into groups according to their use. The standards are made by ISO/FDI for endo-instruments. ISO/ FDI No. 3630/1 deal with the K-type files (ANSI/ADA No. 28), $\mathrm{H}$-files (ANSI/ADA No. 58), barbed broaches and rasps being dealt with ANSI/ ADA No.63, ISO/FDI No. 3630/3 deals with condensers, pluggers, and spreaders (ANSI/ADA No. 71). ${ }^{1}$ The company named "Kerr" was the first to build the K-type instruments keeping ISO standards in mind. Although the stainless steel instruments are still in practice and less flexible that affects the instrumentation and leads to iatrogenic errors, thus the NiTi alloy is introduced. William Buehlerin discovered the alloy in 1963 and named it as NiTiNOL due to its elements, i.e., Nickel (Ni), Titanium ( $\mathrm{Ti})$, and the laboratory where it was produced Navy Ordinance Laboratory (NOL) in Maryland, United States of America. ${ }^{5}$ The NiTi alloy can attain the original shape (austenite) after the application of stress or heat (martensite) in a characteristic

() The Author(s). 2021 Open Access This article is distributed under the terms of the Creative Commons Attribution 4.0 International License (https://creativecommons. org/licenses/by-nc/4.0/), which permits unrestricted use, distribution, and non-commercial reproduction in any medium, provided you give appropriate credit to the original author(s) and the source, provide a link to the Creative Commons license, and indicate if changes were made. The Creative Commons Public Domain Dedication waiver (http://creativecommons.org/publicdomain/zero/1.0/) applies to the data made available in this article, unless otherwise stated. 
called shape memory effect. ${ }^{6}$ In 1988 , Walia et al. proposed the use of NiTiNOL for shaping canals because it is two to three times more flexible, in the same file sizes in comparison to stainless steel. ${ }^{7}$ By the mid-1990, the first commercially available NiTi rotary files had come to market. ${ }^{8}$ Currently, more than 160 automated instrumentation systems are available, manufactured with different $\mathrm{NiTi}$ alloys, heat treated or otherwise, with both superelastic (SE) and shape memory (SME) properties using rotational, reciprocating motion, and centric/ eccentric motion. ${ }^{9}$

The aim of the present article is to describe in detail about various file systems with special consideration on self-adjusting file (SAF).

Based upon the use, instruments in endodontic can be subdivided into four groups: hand-operated, low speed with attachments of latch type, engine-driven instruments, and ultrasonic and sonic instruments. ${ }^{10}$

\section{Hand- or Finger-operated/Manual INSTRUMENTS}

This group includes barbed broach and rasps, K-type files, and $\mathrm{H}$-files and their modifications.

\section{Barbed Broach and Rasps}

They are the oldest of endodontic instruments that are being used for the extirpation of the pulp and enlargement of the canal. The instruments differ in barb size and taper as broach has a taper of $0.007-0.10 \mathrm{~mm} / \mathrm{mm}$ and the rasp $0.015-0.020 \mathrm{~mm} / \mathrm{mm}$. The height of barb is larger in broach in contrast to the rasp. ${ }^{1}$

\section{K-type Instruments}

Originally made from piano wires, later manufactured using stainless steel and currently also by NiTi alloy. The wire of stainless steel is ground into a tapered square or triangular cross-section along the long axis and then twisted to flutes for creation of file or a reamer. The file being more twisted in comparison to reamer, i.e., file has more flutes per unit length than a reamer. Hence, giving reamer a touch of flexibility as compared to K-file.

Modifications of K-type instruments are K-flex and Flex-R files.

\section{$\mathrm{H} /$ Hedstrom Instruments}

A more aggressive instrument than K-type and manufactured by computer-assisted machining technology that cuts the files from a round blank edges facing toward handle, which helps in removing the dentin during the pull motion.

Modifications of H-type instruments are Safety-Hedstrom, Uniflex, and S-files.

Three sizes of hand-operated instruments are available in market: short (21 mm), standard (25 mm), and long (31 $\mathrm{mm})$ and are genuinely cheaper than rotary files. Depending on the system of instrumentation and technique used, they show an equivalent cleaning efficacy in comparison to the rotary instrumentation. However, rotary instrument leads to an improved quality of shaping, providing a better quality of treatment within less time period hence, reducing the operator fatigue. ${ }^{11}$ But it cannot be ignored that hand files give the pleasure of a better tactile sensation than rotary instruments. Various studies have shown that hand files and less tapered rotary files seem to preserve the strength of teeth in a better way than those with increased tapers. Hence, practitioners ought to be careful while choosing instruments for the treatment of root canal and should try to be as much conservative as possible, keeping objectives of treatment in mind. ${ }^{12}$ Furthermore, it was found that the use of hand instruments is particularly an operator-controlled variable factor and may extrude a great number of microbes in comparison to rotary instruments. ${ }^{13}$

\section{LOW-SPEED ENGINE-DRIVEN INSTRUMENTS}

Most commonly Gates-Glidden (GG) and Peeso reamers are used.

Gates-Glidden drill, produced in stainless steel and NiTi varieties, are thin and long shafted which end in a flame-shaped head, with a safe tip to guard against perforations. The flame-shaped head is used gently with an apically directed pressure while cutting action being laterally and generally used for clearance of lingual shoulder in anterior teeth during access preparation and enlargement of the root canal. Gluskin et al., and Isom et al., stated that misused GG drills can dramatically reduce radicular wall thickness. ${ }^{14,15}$ When used adequately, GG instruments are inexpensive, safe, and clinically beneficial. GG can be used safely at 750-1500 rpm. If the operator increases the speed along with excessive pressure and inserts it at an incorrect angle, mishap like strip perforation will occur. Also, cyclic fatigue may cause these instruments to fracture when used in curved canal areas. ${ }^{16}$

Peeso reamers have a long sharp flute connected to a thick shaft cutting laterally and are primarily used for the preparation of post when gutta-percha has to be removed. ${ }^{10}$ The working speed range should be kept in the range of $800-1200 \mathrm{rpm}$ and the operator should remain cautious for the avoidance of excessive preparation and reduction of radicular dentin walls. ${ }^{16}$

\section{Engine-driven Instruments}

The introduction of NiTi rotary instrumentation has been one of the significant revolutions in dentistry and has dramatically changed the manner of preparation of root canals. It has represented efficaciousness in a large number of cases that were otherwise considered to be difficult and are being treated very easily with excellent long-term outcomes with help of rotary instruments. ${ }^{17}$

In dentistry, the NITINOL was first used by Andreasen and Hilleman in the manufacture of orthodontics and specifically in endodontics by Civjan et al. who conceptualized the fabrication of endodontic armamentarium from NiTi alloy, in 1975. Later in 1988, Walia, Brantley, and Gerstein brought the first hand-held $\mathrm{NiTi}$ instrument and a lot of advancements have taken place since then. ${ }^{18,19}$

The engine-driven instruments consist of three groups according to their mode of cutting and details: ${ }^{16}$

\section{Group I}

This group consists of radial-landed instruments by reaming action. ProFile, ProSystemGT, GTX, Quantec, Pow-R, Guidance, K3, and Lightspeed LS1 and LSX fall in this category.

The first commercially introduced rotational instruments were ProFile (Dentsply Tulsa Dental Specialties), Lightspeed (Sybryonendo), and GT (Dentsply Tulsa Dental Specialties) and have a common cross-section, i.e., radial land and created with three-round excavations of a U-Shape. Generally, instruments containing radial lands are considered very safe when accidently taken beyond the proportions of root canal. ${ }^{16}$ They have a reaming action which results in inefficient dentinal cutting when compared to other generation files. Also, the production of smear layer with 
radial landed instruments is different in consistency and amount compared to cutting files. ${ }^{20,21}$ Torsional and cyclic fatigue depend on specific designing of instruments.

Gluskin et al. and Hata et al. in their study on GT files found that shapes prepared stayed centered with less procedural errors. ${ }^{14,22}$ Study done by Peters et al., Park, and Yguel-Henry et al. reported that GT-files shaped root canals similarly like ProFile and Lightspeed; also, the walls were homogeneously planed and smooth. ${ }^{23,24}$

\section{Group II}

This group consists of rotaries that have the triangular cross-sections and an active cutting flute design due to the absence of radial lands. It consists of instruments like ProTaper Var, ProSystem GT, ProTaper Next, RaCe, BioRace, BT Race, Hero 642, HeroShaper, FlexMaster, Mtwo, Sequence, Alpha, ProFile Vortex, and Twisted file.

Yun and Kim stated that ProTaper not only lead to acceptable shapes in blocks faster than GT rotary, ProFile, and Quantec systems but also led to some sort of aberations. In a comparative study on ProTaper and K3 instruments, Bergmans et al. found some differences in exception to some transportation by ProTaper in furcal region. ${ }^{25}$

Rubio et al. used 300 extracted permanent teeth and divided randomly into 10 groups (F360, F6 SkyTaper, Hyflex EDM, iRace, Neoniti, One Shape, ProTaper Next, Revo-S, WaveOne Gold) and concluded that, in cutting area, the ProTaper Next and Reciproc were superior in the coronal third, Neoniti and Hyflex EDM in the middle and apical thirds, and Neoniti and Reciproc overall. Regarding root canal anatomy preservation, all the systems obtained similar results. In noninstrumented areas, the systems were similar in the coronal third, but Reciproc, Neoniti, and WaveOne Gold were better in the middle third, and ProTaper Next, Reciproc, Hyflex EDM, Neoniti, and WaveOne Gold were better in the apical third. ${ }^{26}$

Fayyad and Elgendy compared the efficacy of the cutting ability of two different instruments, concerning changes in the dentin thickness removed and root canal volume, by using multislice computed tomography scanning. They found that ProTaper removed significantly more dentin from the mesiodistal and buccolingual directions of the root canal than the twisted file. No significant difference was recorded for the changes in root canal volume between the two systems. Also, the twisted file (TF) system was found to cut dentin efficiently with more uniform cutting than ProTaper system. ${ }^{27}$

Thompson and Dummer stated that HERO led to some sort of defects when used in canals simulated with acute curves, ${ }^{28}$ but they were found secure than Quantec SC (SybronEndo) instruments. $^{29}$

According to Hübscher et al. FlexMaster has a centered preparation in constricted as well as wider canals ${ }^{30}$ and performed on par with other systems. Clinical studies done by Schäfer et al. stated that FlexMaster represented superior shaping characteristics in contrast to K-files. ${ }^{31}$ Merrett et al. stated that FlexMaster instruments caused little aberrations but took longer time than preparations with RaCe files. ${ }^{32}$

ProFile Vortex has two versions, M-wire type and other manufactured with blue wire. Vortex blue has shown greater cyclic fatigue and torque resistance. ${ }^{16}$ In general, the overall incidence of errors in preparation is low in spite of the fact of having more aggressive cutting action although instrument fracture still is a concern. ${ }^{16}$

\section{Group III}

This group consists of armamentarium with unusual geometry and is used for special cases. Examples being EndoEZE AET, Liberator, WaveOne, Reciproc, One Shape, Hyflex, Revo-S, SAF, and sonic and ultrasonic instruments.

Generally, it constitutes of files with the single-use system. Files like WaveOne reduce the possibility of cross-contamination associated with inability to clean completely and sterilize endodontic instruments. ${ }^{33}$ They contain a plastic color coding in the handle which gets deformed upon sterilization, hence, preventing files from being packed back into the handpiece.

Reciproc system, launched by VDW GMBH, Munich, Germany in 2011, uses a single file reciprocation without prior use of hand files offering a greater flexibility and increased cyclic fatigue resistance than traditional NiTi instruments, but it has its limitations like creation of glide path cannot be done with them before penetration of a file in canal. ${ }^{33,4}$

Thomas et al. (2020) ${ }^{34}$ evaluated and compared the shaping ability of the WaveOne Gold, TRUShape 3D Conforming File, EdgeCoil, and XP-3D Shaper endodontic file systems on oval-shaped canals using micro-computed tomographic (micro-CT) technology and concluded that instrumentation of oval-shaped canals with WaveOne Gold, TRUShape, EdgeCoil, and XP-3D Shaper rotary endodontic instruments similarly increase the volume, surface area, and conicity. None of the file systems were capable of contacting all of the surface areas in any canal.

An addition to endo-armamentarium for instrumentation of canals is the use of ultrasonic instruments (Cavi-endo which is magnetostrictive in action and others being piezoelectric like ENAC, EMS Master 400, and P5 Neutron) and sonic devices (Sonic Air MM 1500, Megasonic 1400, and Endostar). The ultrasonic device holders can fit in a regular type of instrument blanks (e.g., K-files), but sonic needs special devices like Rispi-Sonic, ShaperSonic, TrioSonic, or Heli sonic files. ${ }^{16}$ Mostly, the frequency of fracture at node of vibrations shoots to $10 \%$ when used for greater than 10 minutes. There is higher percentage of preparation error and tendency to reduce the thickness of radicular wall using ultrasonic instruments. ${ }^{35-37}$

\section{Self-adjusting File System (Re-DentNova, Ranana, Israel)}

Both new and traditional files have one thing in common, i.e., a solid central metal core with a rotating blade and flutes to contain or carry off the material cut from the canal space. If there are straight or narrow and round canals, the majority of instruments can adequately achieve goals of shaping but, cases that involve oval or curved canals, rotary instruments whether latest or traditional might fail to meet the challenges. ${ }^{38}$ Most important part of challenge which dictates the success of treatment of the root canal is whether three-dimensional cleaning and shaping or obturation of oval and curved canals, ${ }^{39-42}$ microbiota of the infected canals, ${ }^{43}$ and maintenance of the integrity of radicular dentine. ${ }^{44-50}$

The SAF system helps us achieve what a practitioner generally ignores i.e., a natural 3-D shape, cleaning and irrigating canals especially in case of narrow, oval, or straight with round cross-sections. ${ }^{38}$ It allows continuous flowing of irrigants during preparation. $^{51}$

The SAF system is the first endodontic file without a central solid metal core with an asymmetrical tip. The metal core is a 
thin-walled hollow cylinder made up of NiTi lattice (construction of two longitudinal beams that are connected to each other by two uniquely designed arches to enable compression of file). The arches are connected and harnessed to each other by thin struts that are designed to prohibit the arches from being pulled out of cylinders' wall.

Generally, SAF is available in two diameters: 1.5 and $2.0 \mathrm{~mm}$, which are extremely compressible (Fig. 1). The $1.5 \mathrm{~mm}$ diameter file (with varying lengths of 21,25 , and $31 \mathrm{~mm}$ ) may be compressed to dimensions compared to $20 \mathrm{~K}$-file whereas $2.0 \mathrm{~mm}$ diameter with varying lengths gets compressed like a $35 \mathrm{~K}$-file size. ${ }^{52}$ The $1.5 \mathrm{~mm}$ diameter file is designed for canals that have an initial apical size of ISO 20-40 whereas SAF with a diameter of $2 \mathrm{~mm}$ is used for wider canals with the initial apical size of ISO 35-60. It does not impose its shape on a canal rather it complies with canals original shape (Fig. 2A), both longitudinally and circumferentially. ${ }^{33}$ Working surface of this file is rough (Figs $3 \mathrm{~A}$ and $3 \mathrm{~B}$ ). When SAF is entered into a canal, it gets compressed (Fig. 2B) and adapts to the cross-section, i.e., in a round canal, it obtains a round cross-section whereas, in oval/flat cross-section, it will attain the same with continuous light pressure along the entire circumference of canal, hence, providing a three-dimensional adaptation.

The SAF system is operated with vertical handpieces (Fig. 4) having vibrations of $3000-5000 /$ minute and an amplitude of $0.4 \mathrm{~mm}$ KaVo GENTLE Power dental handpieces can be used with or similarly combined with either a 3LDSY head, MK dent head, Osada, Chirana, or ReDent (RDT3) head. ${ }^{53}$ RDT handpieces can also be used with ones having a NSK-type connector such as X-smart, Endomate, or EndoTouch. The RDT head is made of titanium to resist corrosion that might occur when exposed to sodium hypochlorite.

The SAF generally is meant for one-time use. During operating procedure, SAF is entered in a canal while vibrating and is pushed meticulously till it reaches up to the measured working length. SAF is used in two cycles of 2 minutes each making a total of 4 minutes per canal. ${ }^{53}$ Removal of dentin by SAF is done by back-and-forth motion caused by vibrations and pecking motion applied by the operator combined with continuous irrigation using a special irrigation device, i.e., VATEA, ReDentNova resulting in clean and smooth dentine surface. This irrigation device is attached by a silicon tube to an irrigation hub on shaft of file, providing a

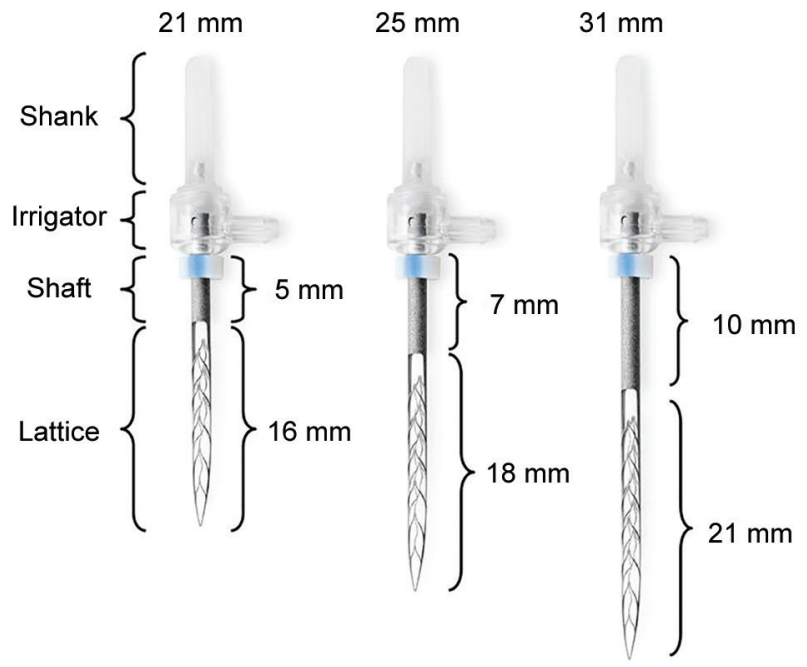

SAF $1.5 \mathrm{~mm}$

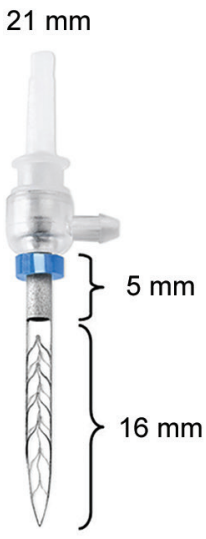

$25 \mathrm{~mm}$

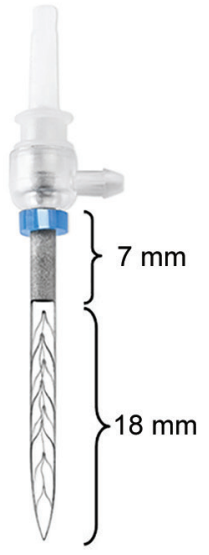

SAF $2.0 \mathrm{~mm}$

Fig. 1: Variable lengths of SAF with diameters (1.5 and $2 \mathrm{~mm}$ )
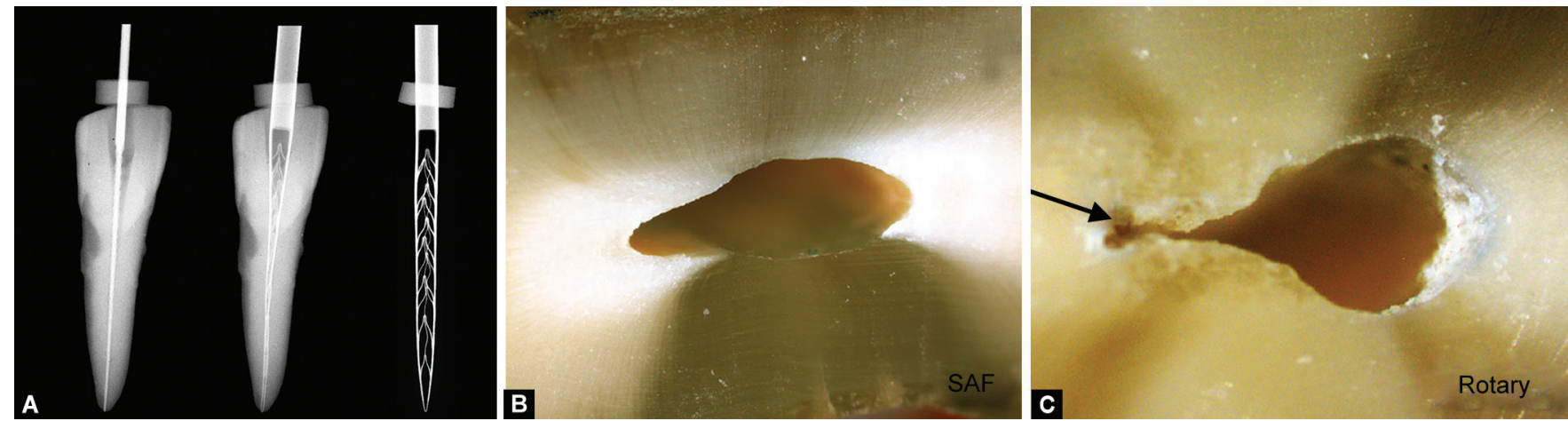

Figs $2 A$ to C: (A) The compressibility and adaptability of SAF\#20; (B and C) The conformation of the SAF vs rotary instrumentation 


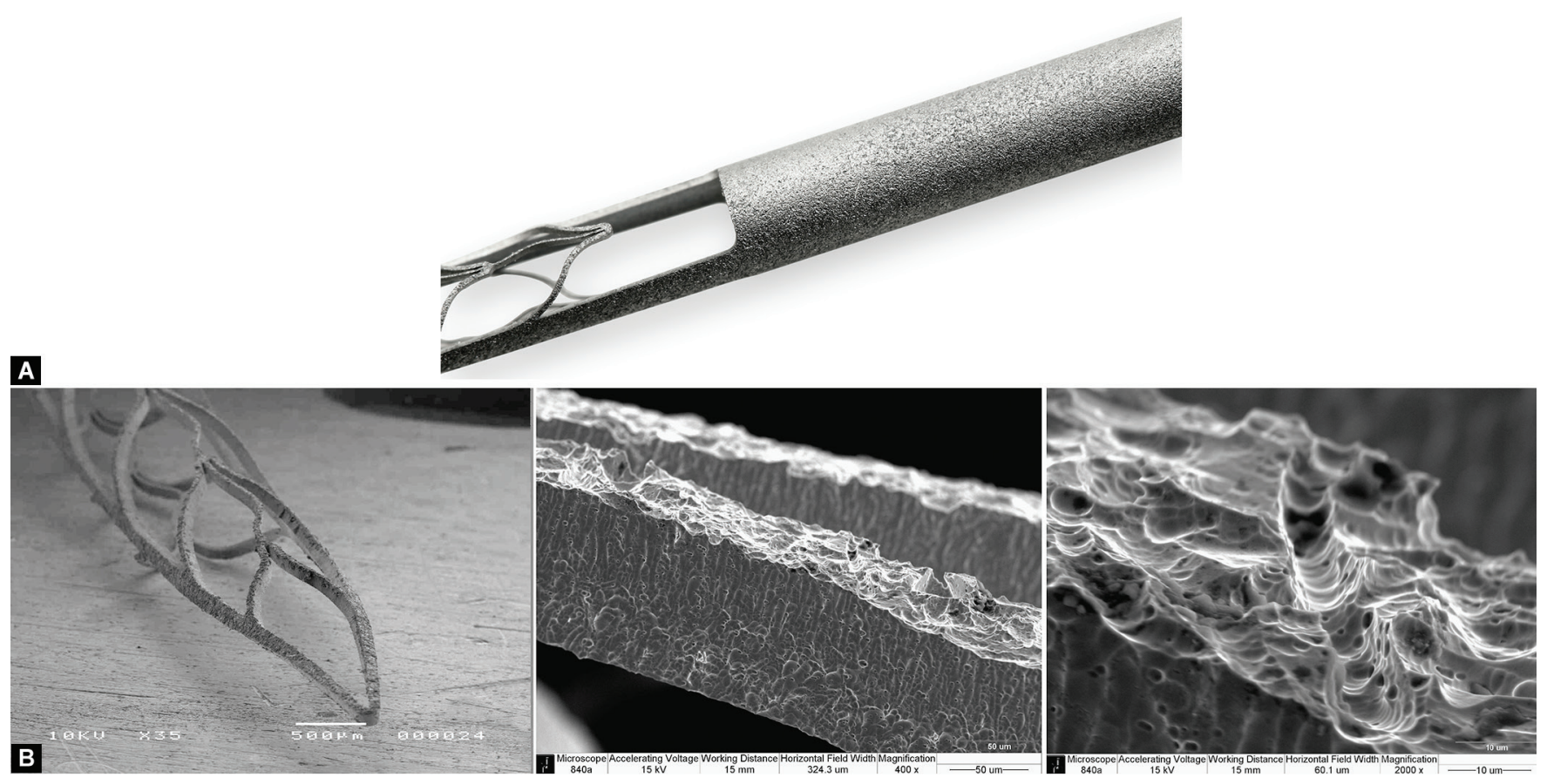

Figs $3 A$ and B: (A) Surface roughness of SAF system; (B) SEM showing the roughness of SAF in three sizes

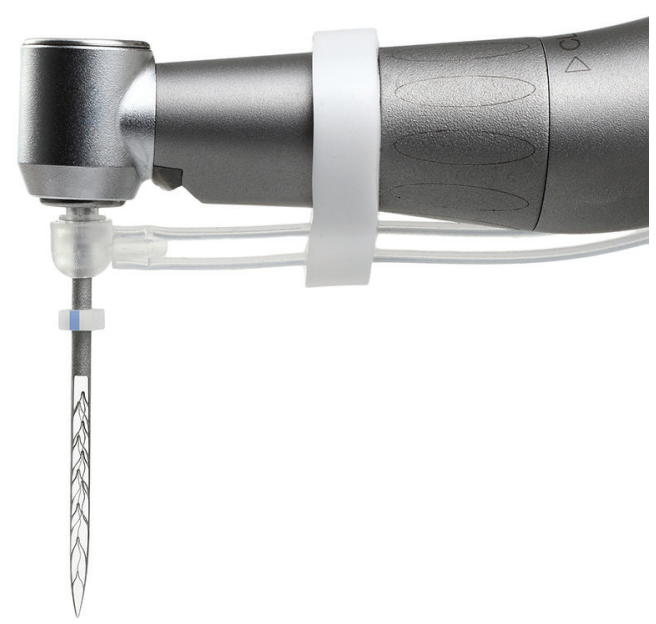

Fig. 4: SAF with handpiece containing an irrigation hub made up of polyethylene tube which is connected to the VATEA irrigation pump

continuous irrigant flow at low pressure with rate of $1-10 \mathrm{~mL} /$ minute, ${ }^{54}$ hence, enhancing the cleaning and shaping of canal system. Various in vitro studies (Paqué F, Peters, 2011, Peters and Paqué, 2011, Lin et al., 2013, Siqueira, 2010) have stated that more contact takes place in contrast to rotary systems, resulting in better debridement and efficacy against microbiota. ${ }^{16}$ Peters and Paqué (2011), and Versiani et al. also stated that the quality of shaping is on par with other rotary instruments. ${ }^{57}$

The study done by Adiguzel states that if SAF is reused, the efficacy of removing dentine decreases. The study furthermore states that SAF is mechanically durable for a continuous operation of a period of 29 minutes and also did not push the irrigant beyond apical foramen. ${ }^{53}$
In an in vitro study done by Capar and Aydinbelge, they concluded that cleaning, shaping, and irrigation with SAF provided similar performance as the agitating systems, like EndoActivator, EndoVac, and passive ultrasonic irrigation, and yielded cleaner canals in comparison to rotary instrumentation. ${ }^{51}$

Various studies with scanning electron microscopy (SEM) have shown that when syringe and needle or any chelating agent is used for removal of debris and smear in apical third of canal, it generally leaves much than desired. But it was also seen that when $3 \% 6 \mathrm{NaOCl}$ and $17 \%$ ethylenediaminetetraacetic acid (EDTA) were used with $\mathrm{SAF}$, the root canal walls were rendered clean and free from debris and smear layer in apical-third region (Fig. 5) because of effective and continuous flow of solutions and mechanical vibrating action of SAF in the region. ${ }^{58,59}$ Metzger et al. stated that SAF leads to debris clearance in $100 \%$ cases in coronal, mid-root, or apical segment of canal having $100 \%$ success for removal of smear layer in coronal and mid-root and $65 \%$ in case of apical root segment and concluded that SAF has a better cleaning, shaping, and led to enhanced adaptation of canal filling materials. ${ }^{47,58}$ Neves et al. stated that SAF has high effectiveness in lessening bacterial populations from infected canals and a better performance than hand instrumentation. ${ }^{60}$ It has also been noticed that when oval canals in distal root of mandibular molars were studied, rotary files left $69 \%$ of unaffected canal wall, even when circumferential movements were applied, and it was found that with the use of SAF, the area was unaffected by procedure before dropped from 69 to $23 \% .^{38}$ In a series of studies done by Paque and Peters ${ }^{42}$ including others have shown a higher percentage (43-53\%) of canal wall remains unaffected by rotational instruments. Also, canal straightening or apical transportation may occur with the use of rotary instrumentation, which may leave large areas of canal uninstrumented and an excessive cutting in some else areas which might cause vertical root fractures during obturation or under the load of mastication. SAF is extremely 


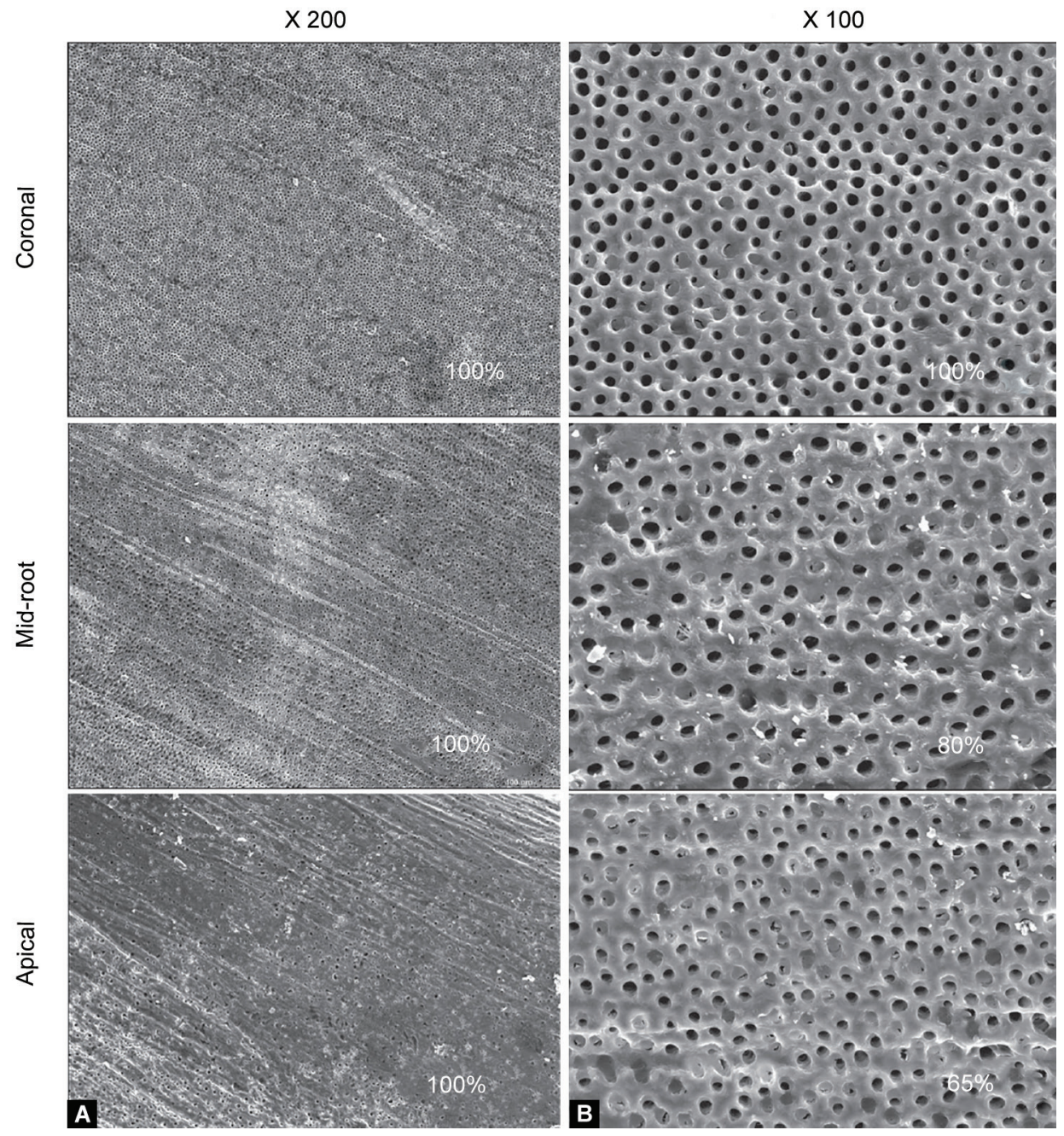

Figs $5 \mathrm{~A}$ and $\mathrm{B}$ : SEM showing the canal being rendered free of debris and smear layer
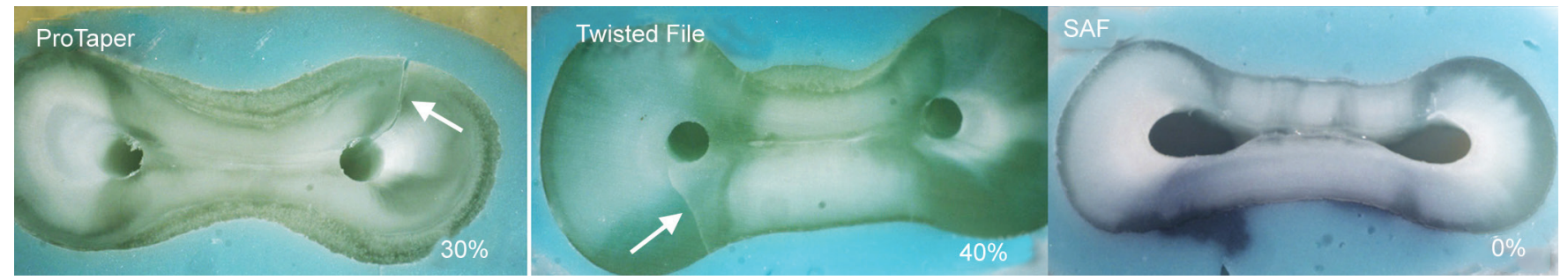

Fig. 6: SAF showing no microcrack formation when compared to rotary instrumentation

flexible hence, minimizing the risk of canal straightening or transportation. Al-Gharrawi HA, Abbas FS. $(2014)^{61}$ concluded that SAF had a better canal centering ability when assessed under CT and showed less amount of transportation of canal in comparison to ProTaper system. The studies have reported that least microcrack formation takes place when SAF is used (Fig. 6). Yoldas et al. ${ }^{49}$ assessed microcrack formation with hand-filing system, Heroshaper, Revo-S, twisted file, and SAF and concluded that all rotaries created microcracks in apical third of the root or canal wall whereas SAF and hand instrumentation lead to satisfactory results with no signs of microcracks. De Deus et al. concluded that the preparation in oval canals by SAF leads to higher pushout bond strength. ${ }^{62}$ De Carvalho et al. evaluated the apical transportation, the centering ability, and the cleaning effectiveness of a reciprocating single-file system associated with different glide path techniques on mesial root canals of 52 mandibular molars randomly distributed into four groups according to the different glide path techniques used before biomechanical preparation with Reciproc System (RS): KF/RS (sizes 10 and $15 \mathrm{~K}$-files), NGP/RS (no glide path, only reciprocating system), PF/RS (sizes 13, 16, and 19 PathFile instruments), and NP (no preparation). Cone-beam computed tomography analysis was performed before and after instrumentation for apical third. They 
concluded that different glide path techniques promoted minimal apical transportation, and the reciprocating single-file system tested remained relatively centralized within the root canal. KF/RS had larger number of debris, with statistically significant difference in comparison with NGP/RS. ${ }^{63}$

Bayram et al. evaluated the frequency of dentinal microcracks observed after root canal preparation with ProTaper Universal (PTU), ProTaper Gold (PTG), SAF, and XP-endo Shaper (XP) instruments using micro-CT analysis on 40 extracted human mandibular premolars having single-canal and straight roots. PTU system significantly increased the percentage rate of microcracks compared with preoperative specimens. No new dentinal microcracks were observed in the PTG, SAF, or XP groups. Root canal preparations with the PTG, SAF, and XP systems did not induce the formation of new dentinal microcracks on straight root canals of mandibular premolars. $^{64}$

Yoldas et al. indicated that the less aggressive instrumentation of the SAF system can prevent dentinal defects during root canal preparation. $^{49}$

Metzeger stated that, unlike other rotary systems, the SAF system is used with an in-and-out grinding motion that inhibits stress formation along the root canal. ${ }^{38}$

Shah et al. compared and evaluated the shaping ability of ProTaper (PT) and SAF system using cone-beam computed tomography to assess their performance in oval-shaped root canals and found that SAF showed better centering ability and lesser canal transportation than the PT only in the buccolingual plane at 6 and $9 \mathrm{~mm}$ levels. The shaping ability of the PT was best in the apical third in both the planes. The SAF had statistically significant better centering and lesser canal transportation in the buccolingual as compared to the mesiodistal plane at the middle and coronal levels. In the mesiodistal plane, the performance of both the systems was parallel. ${ }^{65}$

Paque et al. stated neither conventional nor passive ultrasonic irrigation methods could remove all the radiopaque material: a composite of dentine chips and biofilm that gets packed into isthmus by the action of rotary NiTi files having a potential of microbial growth and proliferation. ${ }^{66}$ Hence, a chance of failure in treatment success. A very recent study has represented that packing of the isthmus with dentin particles with SAF is negligible: $1.7 \%$ of isthmus volume vs $10.1 \%$ that occurred with rotary files. ${ }^{67}$ Also, SAF was found to handle C-shaped root canals with better efficacy in comparison to rotary instrumentation. ${ }^{68}$

In retreatment case of previously filled canal, it was found that $32 \%$ of apical third was still covered with some radiopaque residues in case of rotational instruments but when SAF was used supplementarily, it reduced the load to $7 \%$ and resulted in clean canals than rotary system. ${ }^{69}$

The file separation occurs very rarely in $0.65 \%$ of cases in contrast to rotational files. In comparison to rotary file, it is very easy to retrieve a SAF, as the detached fragment is not screwed in canal (Fig. 7) and the arch/strut of SAF is smaller than the canal, hence can be washed out with irrigation or by the assistance of ultrasonic application or can be simply removed with H-File. ${ }^{38}$ If the operator is not able to remove the file which is located within canal space, still the obturation can be done with warm gutta-percha technique as the material can easily flow through the hollow tube system of SAF.

De Dues et al. conducted a study regarding SAF and stated that less apical debris extrusion is associated with SAF in contrast to hand or rotary files. ${ }^{70}$ Studies have also reported that SAF causes a minimum amount of pain in contrast to WaveOne Gold and ProTaper Next. ${ }^{71}$

In recent advancements toward the use of rotational $\mathrm{NiTi}$ particularly in the primary tooth like Kedo-S has resulted with increased instrument efficacy deciduous dentition as compared to hand files. Kaya et al. reported that SAF is useful for instrumentation of the root canals in deciduous molars as it is involved with a little amount of dentine removal than other file systems, which is very important in consideration of thin dentin and reduced clinical timekeeping paediatric patients in mind. ${ }^{72}$ However, further research needs to be done with the use of these files in deciduous dentition.

Saivabakya et al. stated that single files have shortened the duration of treatment, and their use has led to cost-effectiveness, time-saving, reduced instrument fatigue, and prevented the possible cross-contamination. ${ }^{73}$

\section{Discussion}

In the past few years, it has been noticed that there is a dramatic shift in file designs and materials and the latest rotary systems solve almost all the deficiencies of traditional stainless steel instruments. Rotary instruments have created an exciting and valuable advancement in preparing the canal. There is no doubt that if rotational NiTi is properly used, a better final result with the maintenance of original curvature and shape can be achieved easily. According to the study done by Bergmans et al., ${ }^{6}$ current innovations help us achieve superior results in a predictable manner than those of traditional ones. Rotary systems speed up the treatment so that the effective time of an irrigant is strongly reduced, which otherwise is around 40 minutes ideally. These file systems have better corrosion resistance in comparison to traditional ones. NiTi is an expensive alloy which is very difficult to manufacture and mill, hence, increased cost factor leads to increased procedural cost clinically. In contrast with SS, the latest rotaries have better cleaning efficacy in the apical portion of root canal. According to Singh K et al. (2016) ${ }^{74}$ minimizing the risk of $\mathrm{NiTi}$ instruments with torque-controlled motors should be taken into consideration by not exceeding the recommended speed for the specific system. Tinoco et al. (2014) ${ }^{75}$ stated that all preparation techniques are associated with varied debris extrusion depending

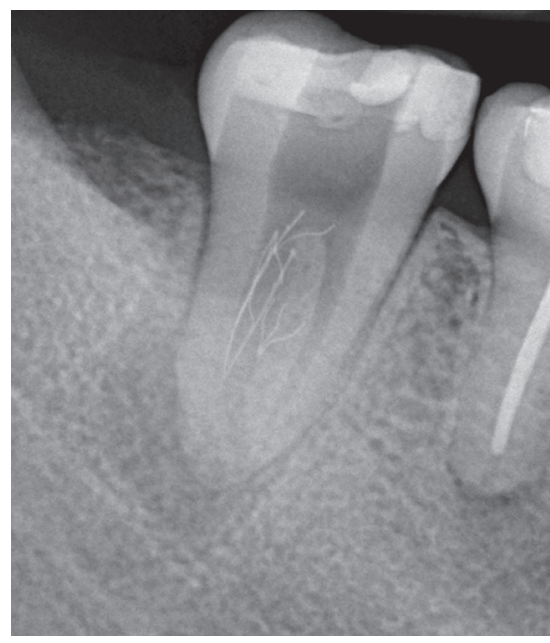

Fig. 7: Detached fragment of SAF 
upon the instrument systems used which generally differ in a crosssection, cutting edge design, taper, tip, configuration, concept of use, their flexibility, type of alloy, number of files used, kinematics, and cutting efficiency. Postoperative pain was associated with preparation procedures which generally arises from an immune response to an irrigant, microorganisms present within debris extruded from canal or overinstrumentation or a foreign body reaction to the filling materials. According to Saha et al., ${ }^{71}$ SAF showed superior results regarding extrusion prevention due to hollow design and continuous, fresh, fully activated irrigation supply. Various studies have also revealed that SAF leads to a cleaner canal that is free from smear and debris in coronal, middle-third, and especially in apical part which sometimes is difficult to achieve while instrumenting with varied rotary systems.

According to Parashos et al. (2004), ${ }^{76}$ Cuhha et al. (2014), ${ }^{77}$ and Plotino et al. (2015), ${ }^{78}$ fracture of automated instruments may occur during preparation of root canal without displaying any sign of strain before use of file. ${ }^{78-80}$ Greatest incidence of fracture is associated with the skill of clinician and number of times the file is being used. Generally, the fracture incidence associated with SS hand instruments falls in the range of $0.7-7.4 \%$ and the incidence of retained fractured rotary $\mathrm{NiTi}$ instruments lies in the range of $0.4-5 \%$ as stated by McGuigan et al. (2013). ${ }^{79}$ Fracture of SS files and reamers is generally associated with overuse and preceded by distortion but in rotary instruments, low yield and tensile strength lead to increased susceptibility of fracture at lower loads. However, limiting the reuse of files decreases the fracture incidence. Singlefile systems and reciprocating instruments have shown lesser incidence of fracture as compared to other file systems. Solomonov et al. $(2015)^{80}$ concluded that SAF displayed a high resistance to the mechanical failure. There can be a possible chance of separation of SAF but the incidence of separation is very low when compared to other instruments. Even if separation takes place, retrieval is very easy. Studies also revealed that SAF displayed significantly less transportation and remained centered as compared to ProTaper at middle and coronal levels in the buccolingual plane of oval canals. In mesiodistal planes, the performance of both systems was parallel. ${ }^{68}$

Kaya et al. ${ }^{72}$ stated that ProFile and SAF rotary systems required similar instrumentation time and significantly less time than conventional ones (K-files). Also, differences in the amount of dentin removal from canal walls varied significantly among the three systems, with SAF removing the smallest amounts and K-files removing the largest amounts. When compared to other files, it was found that SAF can homogenously prepare the flat-oval canals maintaining circumferential goals of canal. The ideal microbiological goal of chemomechanical debridement is the complete eradication of intracanal microbiota along with their toxins. Main efforts should be to maximize disinfection before obturation. Studies have revealed that SAF results in increased volume of infected dentine removal within root canal in contrast to other systems. ${ }^{68,81}$ In a study, Metzger et al. ${ }^{58,59}$ compared the efficacy of obturation with cleaning and shaping of canals with rotary and SAF system and it was revealed that SAF allowed as much as $83 \%$ of canal wall to have an intimate contact with the obturation material as compared to only $55 \%$ in case of rotational files. SAF systems are very easy to use as only single file is being used and help to maintain the patency of root canal without removal of enough dentinal parts.

When the cyclic-fatigue test of ADA was applied, SAF rotated for greater than 150 hours at 900 rpm with $5-\mathrm{mm}$ deflection and no evident mechanical failure, whereas some of the NiTi instruments separated within the first hour or even within few minutes suggesting high durability of the SAF system. ${ }^{58}$

\section{Conclusion}

In the modern era of endodontics, the main goal is to achieve an ideal preparation of the root canal which is being made possible by recently introduced rotary systems. The concept is to ideal shaping and maintaining the original canal curvature which has become the priority and motive for designing the newer generation of $\mathrm{NiTi}$ systems. In contrast to hand instruments, rotary armamentarium has yielded sufficient cleaning ability along with preservation of anatomy of root canal while reducing the operating time and fatigue, which was associated with traditional techniques. Every rotary system has its own benefits; however, the use of SAF has been found to be more efficacious in terms of maintenance of anatomy, mechanical durability, prevention of microcrack formation, bacterial clearance especially in apical third of the canal, less transportation and centering capability by generating a circumferential force, preventing of debris extrusion with its clearance as well as of smear layer. SAF can be used as an alternative system, hence, opening a new era in the field of endodontia especially for ones who are not just content with a faster and easier endodontic treatment but, also, strive for 3-D obturation keeping in mind the concept of minimal invasive dentistry. But still there exists a need for more research in both fields, i.e., adult as well as paediatric endodontics regarding the availability, use, and concept of SAF as at present it is limited only to some parts of the world.

\section{ORCID}

Burhan A Misgar (1) https://orcid.org/0000-0003-2526-956X

Virinder Goyal @ https://orcid.org/0000-0001-5747-466X

Puneet Goyal ๑ https://orcid.org/0000-0001-7957-8160

Tishya Koul ๑ https://orcid.org/0000-0001-7010-3652

Deeksha Sharma @ https://orcid.org/0000-0002-3155-8010

Tavleen Kour $\odot$ https://orcid.org/0000-0002-5509-4994

\section{References}

1. Lyon KF. Endodontic instruments for root canal therapy. Clin Tech Small Anim Pract 2001;16(3):139-150. DOI: 10.1053/svms.2001.28166.

2. Abrar S, Jaiprakash $\mathrm{R}$, Mahala $\mathrm{H}$, et al. Comparative evaluation of efficacy of endodontic irrigant delivery to working length using conventional needle syringe, endovac and self-adjusting file system on prepared mesiobuccal canal of mandibular first molar by using radiographic contrast media: an in vivo study. Int J Dentistry Oral Sci 2019;6(6):706-710. DOI: 10.19070/2377-807519000139.

3. Weine FS. Basis for successful endodontics. In: Endodontic therapy. 6th ed. Mosby: Elsevier; 2004. p. 1-23.

4. Yared G. Canal preparation with only one reciprocating instrument without prior hand filing. A new concept. Int Dent SA 2011;2(2):78-87.

5. Flores AG, Pastenes A. Evolution of instruments in endodonticsliterature review. Int J Dent Oral Health 2019;5(6):1-5. DOI: 10.16966/2378-7090.306.

6. Bergmans L, Van Cleynenbreugel J, Wevers M, et al. Mechanical root canal preparation with NiTi rotary instruments: rationale, performance and safety. Am J Dent 2001;14(5):324-333. PMID: 11803999.

7. Walia $H$, Brantley WA, Gerstein $H$. An initial investigation of the bending and torsional properties of Nitinol root canal files. 
J Endodont 1988;14(7):346-351. DOI: 10.1016/s0099-2399(88) 80196-1.

8. Thompson SA. An overview of nickel-titanium alloys used in dentistry. Int Endod J 2000;33(4):297-310. DOI: 10.1046/j.13652591.2000.00339.x.

9. Gavini G, Santos MD, Caldeira CL, et al. Nickel-titanium instruments in endodontics: a concise review of the state of the art. Braz Oral Res 2018;32(Suppl. 1):e67. DOI: 10.1590/1807-3107bor-2018.vol32.0067.

10. Shaping and cleaning of the radicular space: instruments and techniques. In: Grossman's endodontic practice. 13th ed. Wolters Kluwer India Pvt. Ltd.; 2014. p. 291.

11. Panchal V, Jeevanandan G, Erulappan SM. Comparison between the effectiveness of rotary and manual instrumentation in primary teeth: a systematic review. Int J Clin Pediat Dent 2019;12(4):340. DOI: 10.5005/jp-journals-10005-1637.

12. Acharya N, Hasan MR, Kafle D, et al. Effect of hand and rotary instruments on the fracture resistance of teeth: an in vitro study. Dent J 2020;8(2):38. DOI: 10.3390/dj8020038.

13. Ghivari SB, Kubasad GC, Deshpande P. Comparative evaluation of apical extrusion of bacteria using hand and rotary systems: an in vitro study. J Conserv Dent 2012;15(1):32. DOI: 10.4103/0972-0707.92603.

14. Gluskin AH, Brown DC, Buchanan LS. A reconstructed computerized tomographic comparison of $\mathrm{Ni}$-Ti rotary $\mathrm{GT}^{\mathrm{TM}}$ files versus traditional instruments in canals shaped by novice operators. Int Endod J 2001;34(6):476-484. DOI: 10.1046/j.1365-2591.2001.00422.x.

15. Isom TL, Marshall JG, Baumgartner JC. Evaluation of root thickness in curved canals after flaring. J Endod 1995;21(7):368-371. DOI: 10.1016/ S0099-2399(06)80972-6.

16. Hargreaves KM, Berman LH. Cleaning and shaping the root canal system. In: Cohens pathways of pulp. 11th ed. Elsevier Inc.; 2016. p. 209-279.

17. Peters OA, Paqué F. Current developments in rotary root canal instrument technology and clinical use: a review. Quintessence Int 2010;41(6):479-488. PMID: 20490390.

18. Andreasen GF, Hilleman TB. An evaluation of 55 cobalt substituted Nitinol wire for use in orthodontics. J Am Dent Assoc 1971;82(6): 1373-1375. DOI: 10.14219/jada.archive.1971.0209.

19. Civjan S, Huget EF, DeSimon LB. Potential applications of certain nickel-titanium (nitinol) alloys. J Dent Res 1975;54(1):89-96. DOI: 10.1177/00220345750540014301.

20. Park H. A comparison of Greater Taper files, ProFiles, and stainless steel files to shape curved root canals. Oral Surg Oral Med Oral Pathol Oral Radiol Endod 2001;91(6):715-718. DOI: 10.1067/moe.2001.114159.

21. Yun HH, Kim SK. A comparison of the shaping abilities of 4 nickeltitanium rotary instruments in simulated root canals. Oral Surg Oral Med Oral Pathol Oral Radiol Endod 2003;95(2):228-233. DOI: 10.1067/ moe.2003.92.

22. Hata G, Hayami S, Weine FS, et al. Effectiveness of oxidative potential water as a root canal irrigant. Int Endod J 2001;34(4):308-317. DOI: 10.1046/j.1365-2591.2001.00395.x.

23. Peters OA, Schönenberger K, Laib A. Effects of four Ni-Ti preparation techniques on root canal geometry assessed by micro computed tomography. Int Endod J 2001;34(3):221-230. DOI: 10.1046/j.13652591.2001.00373.x.

24. Yguel-Henry S, Vannesson H, Von Stebut J. High precision, simulated cutting efficiency measurement of endodontic root canal instruments: influence of file configuration and lubrication. J Endod 1990;16(9):418-422. DOI: 10.1016/S0099-2399(06)81883-2.

25. Bergmans L, Van Cleynenbreugel J, Beullens M, et al. Progressive versus constant tapered shaft design using NiTi rotary instruments. Int Endod J 2003;36(4):288-295. DOI: 10.1046/j.13652591.2003.00650.x.

26. Rubio J, Zarzosa Jl, Pallares A. Comparison of shaping ability of 10 rotary and reciprocating systems: an in vitro study with AutoCAD Acta Stomatol Croat 2017;51(3):207-216. DOI: 10.15644/asc51/3/4.

27. Fayyad DM, Elgendy AA. Cutting efficiency of twisted versus machined nickel-titanium endodontic files. Journal of endodontics. 2011 Aug 1;37(8):1143-1146. PMID: 21763910.
28. Thompson SA, Dummer PM. Shaping ability of Hero 642 rotary nickel-titanium instruments in simulated root canals: Part 2. Int Endod J 2000;33(3):255-261. DOI: 10.1046/j.1365-2591.2000.00288.x.

29. Hülsmann $M$, Schade $M$, Schäfers F. A comparative study of root canal preparation with HERO 642 and Quantec SC rotary $\mathrm{Ni}-\mathrm{Ti}$ instruments. Int Endod J 2001;34(7):538-546. DOI: 10.1046/j.13652591.2001.00431.x.

30. Hübscher W, Barbakow F, Peters OA. Root-canal preparation with FlexMaster: canal shapes analysed by micro-computed tomography. Int Endod J 2003;36(11):740-747. DOI: 10.1046/j.13652591.2003.00723.x.

31. Schäfer E, Schulz-Bongert U, Tulus G. Comparison of hand stainless steel and nickel titanium rotary instrumentation: a clinical study. J Endod 2004;30(6):432-435. DOI: 10.1097/00004770-20040600000014.

32. Merrett SJ, Bryant ST, Dummer PM. Comparison of the shaping ability of RaCe and FlexMaster rotary nickel-titanium systems in simulated canals. J Endod 2006;32(10):960-962. DOI: 10.1016/j.joen.2006.03.002.

33. Sharma $P$, Goel M, Verma S, et al. Entering a new era in endodontics with revolutionary single file systems: a comprehensive review. EC Dental Sci 2016;5:1100-1122. Corpus ID: 212545477.

34. Thomas JP, Lynch M, Paurazas S, Askar M. Micro-computed Tomographic Evaluation of the Shaping Ability of WaveOne Gold, TRUShape, EdgeCoil, and XP-3D Shaper Endodontic Files in Single, Oval-shaped Canals: An In Vitro Study. Journal of endodontics. 2020 Feb 1;46(2):244-251.

35. Loushine RJ, Weller RN, Hartwell GR. Stereomicroscopic evaluation of canal shape following hand, sonic, and ultrasonic instrumentation. J Endod 1989;15(9):417-421. DOI: 10.1016/s0099-2399(89)80175-x.

36. McCann JT, Keller DL, LaBounty GL. Remaining dentin/cementum thickness after hand or ultrasonic instrumentation. J Endod 1990;16(3):109-113. DOI: 10.1016/S0099-2399(06)81584-0.

37. Zmener O, Banegas G. Comparison of three instrumentation techniques in the preparation of simulated curved root canals. Int Endod J 1996;29(5):315-319. DOI: 10.1111/j.1365-2591.1996.tb01391.x.

38. Metzger Z. The self-adjusting file (SAF) system: An evidence-based update. Journal of conservative dentistry: JCD. 2014 Sep;17(5):401. PMID: 25298639.

39. Peters $\mathrm{OA}$, Peters $\mathrm{Cl}$, Schonenberger $\mathrm{K}$, et al. ProTaper rotary root canal preparation: assessment of torque and force in relation to canal anatomy. Int Endod J 2003;36(2):93-99. DOI: 10.1046/j.13652591.2003.00628.x.

40. De-Deus G, Barino B, Zamolyi RQ, et al. Suboptimal debridement quality produced by the single-file $\mathrm{F} 2$ ProTaper technique in ovalshaped canals. J Endod 2010;36(11):1897-1900. DOI: 10.1016/j. joen.2010.08.009.

41. Paqué $F$, Balmer $M$, Attin $T$, et al. Preparation of oval-shaped root canals in mandibular molars using nickel-titanium rotary instruments: a micro-computed tomography study. J Endod 2010;36(4):703-707. DOI: 10.1016/j.joen.2009.12.020.

42. Paqué $F$, Peters OA. Micro-computed tomography evaluation of the preparation of long oval root canals in mandibular molars with the self-adjusting file. J Endod 2011;37(4):517-521. DOI: 10.1016/j. joen.2010.12.011.

43. Siqueira Jr JF, Alves FR, Almeida BM, et al. Ability of chemomechanical preparation with either rotary instruments or self-adjusting file to disinfect oval-shaped root canals. J Endod 2010;36(11):1860-1865. DOI: 10.1016/j.joen.2010.08.001.

44. Shemesh H, Bier CA, Wu MK, et al. The effects of canal preparation and filling on the incidence of dentinal defects. Int Endod J 2009;42(3):208-213. DOI: 10.1111/j.1365-2591.2008.01502.x.

45. Bier CA, Shemesh $\mathrm{H}$, Tanomaru-Filho $M$, et al. The ability of different nickel-titanium rotary instruments to induce dentinal damage during canal preparation. J Endod 2009;35(2):236-238. DOI: 10.1016/j. joen.2008.10.021.

46. Metzger Z, Zary R, Cohen R, et al. The quality of root canal preparation and root canal obturation in canals treated with rotary versus self-adjusting files: a three-dimensional micro-computed 
tomographic study. J Endod 2010;36(9):1569-1573. DOI: 10.1016/ j. joen.2010.06.003.

47. De-Deus G, Souza EM, Barino B, et al. The self-adjusting file optimizes debridement quality in oval-shaped root canals. J Endod 2011;37(5):701-705. DOI: 10.1016/j.joen.2011.02.001.

48. Adorno CG, Yoshioka T, Suda H. Crack initiation on the apical root surface caused by three different nickel-titanium rotary files at different working lengths. J Endod 2011;37(4):522-525. DOI: 10.1016/ j. joen.2010.12.002.

49. Yoldas O, Yilmaz S, Atakan G, et al. Dentinal microcrack formation during root canal preparations by different NiTi rotary instruments and the self-adjusting file. J Endod 2012;38(2):232-235. DOI: 10.1016/ j. joen.2011.10.011.

50. Hin ES, Wu MK, Wesselink PR, et al. Effects of self-adjusting file, Mtwo, and ProTaper on the root canal wall. J Endod 2013;39(2):262-264. DOI: 10.1016/j.joen.2012.10.020. During root canal preparations by different NiTi rotary instruments and the self-adjusting file. J Endod 2012;38(2):232-235. DOI: 10.1016/j. joen.2011.10.011.

51. Çapar ID, Ari Aydinbelge H. Effectiveness of various irrigation activation protocols and the self-adjusting file system on smear layer and debris removal. Scanning 2014;36(6):640-647. DOI: 10.1002/ sca.21171.

52. Metzger Z. From files to SAF: 3D endodontic treatment is possible at last. Alpha Omegan 2011;104(1-2):36-44. PMID: 21905365.

53. Adigüzel Ö. A literature review of self adjusting file. Int Dent Res 2011;1(1):18-25. DOI: 10.5577/intdentres.2011. vol1.no1.4.

54. Yesh S, Code QR. Self-adjusting file system: a review. Int. Journal of Biomedical and Advance Research 2018;9(4):128-131.

55. Peters OA, Paque F: Root canal preparation of maxillary molars with the self-adjusting file: a micro-computed tomography study. J Endod 37:53, 2011

56. Lin J, Shen Y, Haapasalo M: A comparative study of biofilm removal with hand, rotary nickel-titanium, a self-adjusting file instrumentation using a novel in vitro biofilm model, J Endod 2013;39:658.

57. Versiani MA, Leoni GB, Steier L, et al. Micro-computed tomography study of oval-shaped canals prepared with the self-adjusting File, Reciproc, WaveOne, and Protaper universal systems. J Endod 2013;39(8):1060-1066. DOI: 10.1016/j.joen.2013.04.009.

58. Metzger Z, Teperovich E, Cohen R, et al. The self-adjusting file (SAF). Part 3: removal of debris and smear layer-a scanning electron microscope study. J Endod 2010;36(4):697-702. DOI: 10.1016/j. joen.2009.12.037.

59. Metzger Z, Teperovich E, Zary R, et al. The self-adjusting file (SAF). Part 1: respecting the root canal anatomy-a new concept of endodontic files and its implementation. J Endod 2010;36(4):679-690. DOI: 10.1016/j.joen.2009.12.036.

60. Neves MA, Rôças IN, Siqueira Jr JF. Clinical antibacterial effectiveness of the self-adjusting file system. Int Endod J 2014;47(4):356-365. DOI: 10.1111/iej.12151.

61. Al-Gharrawi HA, Abbas FS. An evaluation of canal transportation and centering ability at different levels of root canals prepared by selfadjusting file using computed tomography (A comparative study). Computerized tomography (CT). 2014;10:11.

62. De-Deus G, Accorsi-Mendonça T, e Silva LD, et al. Self-adjusting file cleaning-shaping-irrigation system improves root-filling bond strength. J Endod 2013;39(2):254-257. DOI: 10.1016/j.joen. 2012.10.026.

63. De Carvalho GM, Junior ECS, Garrido ADB, et al. Apical transportation, centering ability, and cleaning effectiveness of reciprocating singlefile system associated with different glide path techniques. J Endod 2015;41(12):2045-2049. DOI: 10.1016/j.joen.2015.09.005.

64. Bayram HM, Bayram E, Ocak M, Uygun AD, Celik HH. Effect of ProTaper Gold, Self-Adjusting File, and XP-endo Shaper instruments on dentinal microcrack formation: a micro-computed tomographic study. Journal of endodontics. 2017 Jul 1;43(7):1166-1169. PMID: 28476466.
65. Shah DY, Wadekar SI, Dadpe AM, et al. Canal transportation and centering ability of protaper and self-adjusting file system in long oval canals: an ex-vivo cone-beam computed tomography analysis. J Conserv Dent 2017;20(2):105-109.

66. Paqué $F$, Boessler $C$, Zehnder M. Accumulated hard tissue debris levels in mesial roots of mandibular molars after sequential irrigation steps. Int Endod J 2011;44(2):148-153. DOI: 10.1111/j.13652591.2010.01823.x.

67. Paqué $\mathrm{F}, \mathrm{Al}$-Jadaa A, Kfir A. Hard-tissue debris accumulation created by conventional rotary versus self-adjusting file instrumentation in mesial root canal systems of mandibular molars. Int Endod J 2012;45(5):413-418. DOI: 10.1111/j.1365-2591.2011.01991.x.

68. Solomonov M, Paqué F, Fan B, et al. The challenge of C-shaped canal systems: a comparative study of the self-adjusting file and ProTaper. J Endod 2012;38(2):209-214. DOI: 10.1016/j.joen.2011.10.022.

69. Abramovitz I, Relles-Bonar S, Baransi B, et al. The effectiveness of a self-adjusting file to remove residual gutta-percha after retreatment with rotary files. Int Endod J 2012;45(4):386-392. DOI: 10.1111/ j.1365- 2591.2011.01988.x.

70. De-Deus GA, Silva EJ, Moreira EJ, et al. Assessment of apically extruded debris produced by the self-adjusting file system. J Endod 2014;40(4):526-529. DOI: 10.1016/j.joen.2013.07.031.

71. Saha SG, Gupta RK, Bhardwaj A, et al. Comparison of the incidence of postoperative pain after using a continuous rotary system, a reciprocating system, and a Self-Adjusting File system in single-visit endodontics: a prospective randomized clinical trial. J Conserv Dent 2018;21(3):333. DOI: 10.4103/JCD.JCD_336_17.

72. Kaya E, Elbay M, Yiğit D. Evaluation of the Self-Adjusting File system (SAF) for the instrumentation of primary molar root canals A microcomputed tomographic study. Eur J Paediatr Dent 2017;18:105. PMID: 28598180.

73. Sivabakya TK, Hemasathya B, Balagopal S. LESS IS MORE-SINGLE FILE SYSTEM IN ENDODONTICS-A REVIEW. Journal of Clinical Dental Updates and Research. 2016;7(2):31-6.

74. Singh K, Bindra SS, Singh G, Kaur H. Endodontic rotary systems-a review. Journal of Advanced Medical and Dental Sciences Research. $2016 \mathrm{Jul} 1 ; 4(4): 62$.

75. Tinoco JM, De-Deus G, Tinoco EM, Saavedra F, Fidel RA, Sassone LM Apical extrusion of bacteria when using reciprocating single-file and rotary multifile instrumentation systems. International Endodontic Journal. 2014 Jun;47(6):560-566.

76. Parashos P, Gordon I, Messer HH. Factors influencing defects of rotary nickel-titanium endodontic instruments after clinical use. Journal of endodontics. 2004 Oct 1;30(10):722-725.

77. Cunha RS, Junaid A, Ensinas P, Nudera W, da Silveira Bueno CE. Assessment of the separation incidence of reciprocating WaveOne files: a prospective clinical study. Journal of endodontics. $2014 \mathrm{Jul}$ 1;40(7):922-924.

78. Plotino G, Grande NM, Porciani PF. Deformation and fracture incidence of Reciproc instruments: a clinical evaluation. International endodontic journal. 2015 Feb;48(2):199-205.

79. McGuigan MB, Louca C, Duncan HF. Endodontic instrument fracture: causes and prevention. British dental journal. 2013 Apr;214(7):341-348.

80. Solomonov M, Ben-Itzhak J, Kfir A, Von Stetten O, Lipatova E, Farmakis ET. Self-adjusting file (SAF) separation in clinical use: A preliminary survey among experienced SAF users regarding prevalence and retrieval methods. Journal of conservative dentistry: JCD. 2015 May;18(3):200.

81. de Melo Ribeiro MV, Silva-Sousa YT, Versiani MA, Lamira A, Steier L, Pécora JD, de Sousa-Neto MD. Comparison of the cleaning efficacy of self-adjusting file and rotary systems in the apical third of oval-shaped canals. Journal of Endodontics. 2013 Mar 1;39(3):398. 